\title{
Optimizing Process Parameter Machining From Combined Energy Consumption and Material Removal Rate On ST 41-3
}

\author{
Teguh Prasetyo ${ }^{1}$, Mukhib Bussafi ${ }^{2}$, Nachnul Anshori, Mahrus K. Umami ${ }^{3}$, Mirza Pramudia ${ }^{4}$ \\ Department of Industrial \& Mechanical Engineering \\ University of Trunojoyo Madura \\ Bangkalan, Indonesia \\ 1'teguh.prasetyo@trunojoyo.ac.id, ${ }^{2}$ mukhibbussafi@gmail.com, ${ }^{3}$ mahrus_umami@yahoo.co.id, ${ }^{4}$ mpramudia@gmail.com
}

\begin{abstract}
Machining processes are spent a lot of energy in the manufacturing industry. On the other hand, we understand that energy should be minimum. The purpose of this study is to find the optimal machining parameters that allow the most energyefficient processes. The study focused on optimization of parametric process machining on combination energy consumption and material removal rate in machining on Steel ST 41-3. The data were evaluated using the Taguchi method and TOPSIS (Technique for Order Preference by Similarity to Ideal Solution). Finally, the research has successfully to get the best parameter of machining are cutting speed of $22.8(\mathrm{~mm} / \mathrm{min})$, feeds $(0.01 \mathrm{~mm} /$ tooth $)$ and the depth of cuts $(1.5 \mathrm{~mm})$. At the parameter machining setting have the lowest energy used level. Experiments in this study will be carried out in a laboratory scale, and the results of these experiments can be used as a reference in its application in the industrial world.
\end{abstract}

Keywords-Parameter Machining; Energy Consumption; Material Removal Rate; Taguchi; TOPSIS.

\section{INTRODUCTION}

In the last few years, efficiencies energy is a big issue in manufacturing processes. Because the most cost in manufacturing processes comes from energy consumption. Material Removal Rate (MRR) is an important aspect of the machining process to be optimized [1]. MRR has an important influence on productivity of a manufacturing industry, especially in the metal cutting process (the metal cutting process becomes vital) in the rouging stage (rough cultivation stage before finishing) [2]. [3] Optimizing energy consumption and MRR can improve the efficiency of machining processes in the manufacturing industry.

Optimization of energy consumption and MRR responses will be carried out by determining the optimal value of machining parameters that affect both responses. Machining parameters (factors) used include cutting speed, feed, and depth of cut [4]. In this study, a combination of Taguchi method and TOPSIS (Technique for Order Preference by Similarity to Ideal Solution) is used to determining the optimal value of machining parameters. Experiments in this study will be carried out in a laboratory scale, then the results of these experiments can be used as a reference in its application in the industrial world. Taguchi method [5] is a method of optimizing single response process parameters. [6] The Taguchi method can provide optimal results with a number of more efficient trials. The use of TOPSIS method in this study is used to complete the determination of a combination of factor levels that can provide the most optimal results for the response (energy consumption and MRR).

\section{LITERATURE REVIEW}

\section{A. Material Removal Rate (MRR)}

Material Removal Rate is one indicator that can be used to measure the performance of the machining process [8]. MRR which is defined as the amount of material volume wasted per unit of time [9] is influenced by several parameters. These parameters are cutting speed (v), feed (z), and depth of cut (d) [5] [6].

$$
\begin{gathered}
v=\frac{\pi \cdot d \cdot n}{1000} \\
v_{f}=f_{z} \cdot n \cdot z \\
M R R=\frac{d \cdot w \cdot v_{f}}{1000}
\end{gathered}
$$

Where,

$$
\begin{array}{ll}
z=\text { tooth } & v=\text { cutting speed }(\mathrm{m} / \mathrm{min}) \\
D=\text { diameter }(\mathrm{mm}) & v_{f}=\text { feed }(\mathrm{mm} / \mathrm{min}) \\
n=\text { RPM } & f_{z}=\text { feed }(\mathrm{mm} / \text { tooth }) \\
w=\text { width }(\mathrm{mm}) & d=\text { depth of cut }(\mathrm{mm})
\end{array}
$$

\section{METHODS}

\section{A. Taguchi Method}

Taguchi method is an orthogonal matrix design that is used to analyze parameters with little experiment. The optimal level process value is the level that has the highest relationship. 
Furthermore, through ANOVA analysis can find out which process parameters are important

optimal and efficient results with relatively easy applications [8].

\section{B. Technique for Order Preference by Similarity to Ideal Solution (TOPSIS)}

TOPSIS is one method of Multiple Criteria Decision Making (MCDM). The principle of the TOPSIS method is that the chosen alternative must have the shortest distance from the positive solution or the negative solution from a geometric point of view [3].

\section{Tools and Material}

\section{HSS Endmill}

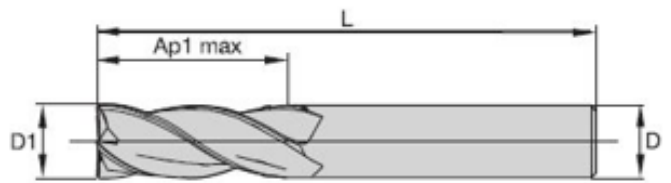

$\mathrm{D} 1=6 \mathrm{~mm}$

$\mathrm{D}=8 \mathrm{~mm}$

Ap1 $\max =15 \mathrm{~mm}$

Fig. 1. Figure 1. HSS Endmill [12]

2. CNC ProMill 8000

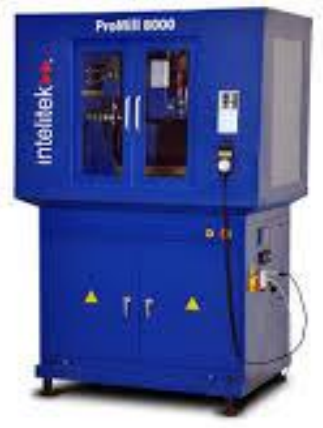

Fig. 2. Figure 2. CNC ProMill 8000 [10]

3. $\mathrm{ST} 41-3$

ST 41-3 is one type of material that is often used in the industrial world. The use of ST 41-3 is mainly used in making bars, plates, structural shapes, axles, connecting rods, shafting etc [11].

\section{Power Meter Hioki 3286-20}

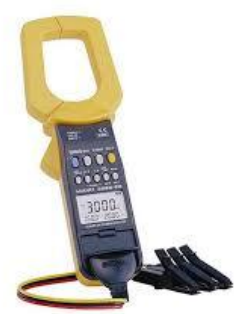

Fig 3. Power Meter Hioki 3286-20 [12]

\section{RESULTS AND DISCUSSION}

TABLE I. LEVEL COMBINATION OF MACHINING PARAMETER PROCESS

\begin{tabular}{|c|l|c|c|c|}
\hline No & $\begin{array}{c}\text { Machining } \\
\text { Parameter } \\
\text { Process }\end{array}$ & $\begin{array}{c}\text { Level 1 } \\
(\mathbf{1})\end{array}$ & $\begin{array}{c}\text { Level 2 } \\
(\mathbf{2})\end{array}$ & $\begin{array}{c}\text { Level 3 } \\
(\mathbf{3})\end{array}$ \\
\hline 1 & $\begin{array}{l}\text { Cutting speed } \\
(v), \mathrm{m} / \mathrm{min}\end{array}$ & 22,8 & 33,9 & 45,0 \\
\hline 2 & $\begin{array}{l}\text { feed }(f z), \\
\text { mm/tooth }\end{array}$ & 0,0100 & 0,0125 & 0,0150 \\
\hline 3 & $\begin{array}{l}\text { Dept of cut }(\mathrm{d}), \\
\mathrm{mm}\end{array}$ & 0,150 & 0,825 & 1,500 \\
\hline
\end{tabular}

TABLE II. EXPERIMENT DATA

\begin{tabular}{|c|c|c|c|c|c|}
\hline \multirow{2}{*}{ No } & \multicolumn{2}{|c|}{$\begin{array}{c}\text { Treatment } \\
\text { Factor } \\
\text { code }\end{array}$} & \multicolumn{2}{c|}{ Repetition 1 } \\
\cline { 2 - 6 } & $\boldsymbol{v}$ & $f z$ & $d$ & $\begin{array}{c}\text { Wcutting } \\
\text { (Wh) }\end{array}$ & $\begin{array}{c}\text { MRR } \\
\text { (Vol/min) }\end{array}$ \\
\hline 1 & 1 & 1 & 1 & 5,88 & 43,3929 \\
\hline 2 & 1 & 2 & 2 & 6,0919 & 293,7363 \\
\hline 3 & 1 & 3 & 3 & 5,0875 & 656,7568 \\
\hline 4 & 2 & 1 & 2 & 4,8958 & 356,4 \\
\hline 5 & 2 & 2 & 3 & 4,3333 & 810 \\
\hline 6 & 2 & 3 & 1 & 2,5764 & 87,2 \\
\hline 7 & 3 & 1 & 3 & 5,2603 & 852,6316 \\
\hline 8 & 3 & 2 & 1 & 2,625 & 108 \\
\hline 9 & 3 & 3 & 2 & 3,2406 & 703,4211 \\
\hline
\end{tabular}

\section{A. ANOVA Consumption Energy}

Steps taken to identify factors that significantly influence the response variable. This is done on the average of the response variables (energy consumption and MRR) in the milling process that arises due to treatment factors. In this ANOVA test the error value $(\alpha)$ is $5 \%$. Here are the hypotheses used.

a. Effect of cutting speed (v)

$\mathrm{H} 0=$ There is no significant effect of cutting speed factor (v) on energy consumption

$\mathrm{H} 1=$ There is a significant effect of cutting speed factor (v) on energy consumption

b. Influence effect (fz)

$\mathrm{HO}=$ There is no significant effect of feed factor (fz) on energy consumption

$\mathrm{H} 1=$ There is a significant influence of the feed factor (fz) on energy consumption

c. Effect of cutting depth (d)

$\mathrm{H} 0=$ There is no significant influence from the cutting depth factor (d) on energy consumption

$\mathrm{H} 1=$ There is a significant influence from the cutting depth factor (d) on energy consumption

If Fcount > FTabel: Reject H0 or Fcount $\leq$ FTabel: Accept H0 
TABLE III. ANOVA MEAN ENERGY CONSUMPTION

\begin{tabular}{|c|c|c|c|c|c|}
\hline Source & DF & SS & MS & F-VALUE & PC \\
\hline $\mathbf{v}$ & 2 & 5,45 & 2,7 & 89,59 & $40,31 \%$ \\
\hline $\mathbf{f z}$ & 2 & 4,02 & 2 & 66.055 & $29,60 \%$ \\
\hline $\mathbf{d}$ & 2 & 3,84 & 1,9 & 63.139 & $28,27 \%$ \\
\hline Error & 2 & 0,06 & 0 & & $1,82 \%$ \\
\hline Total & 8 & & & & $100 \%$ \\
\hline
\end{tabular}

Based on the percentage contribution (PC) in table III it can be seen that the cutting speed factor $(40.308 \%)$ has the greatest influence.

\begin{tabular}{|c|c|c|c|c|c|c|c|c|c|}
\hline \multirow[b]{2}{*}{ Level } & \multicolumn{3}{|c|}{ Cutting Speed } & \multicolumn{3}{|c|}{ Feed } & \multicolumn{3}{|c|}{ Depth of cut } \\
\hline & 1 & 2 & 3 & 1 & 2 & 3 & 1 & 2 & 3 \\
\hline $\mathrm{N}$ & 3 & 3 & 3 & 3 & 3 & 3 & 3 & 3 & 3 \\
\hline Mean & 5,56 & 4,08 & 3,778 & 5,4 & 4,31 & 3,8 & 5 & 5 & 3,57 \\
\hline Grouping & A & B & B & A & B & B & B & A & A \\
\hline
\end{tabular}

\section{B. ANOVA Material Removal Rate}

This ANOVA test aims to find the treatment factors (cutting speed, in feed and cutting depth) which significantly affect the material removal rate. In this ANOVA test the error value $(\alpha)$ is $5 \%$. Here are the hypotheses used.

a. Effect of cutting speed (v)

$\mathrm{H} 0=$ There is no significant effect of the cutting speed factor (v) on the material removal rate

$\mathrm{H} 1$ = There is a significant effect of the cutting speed factor (v) on the material removal rate

b. Influence effect (fz)

$\mathrm{H} 0=$ There is no significant effect of feed factor ( $f z)$ on the material removal rate

$\mathrm{H} 1$ = There is a significant effect of feed factor (fz) on material removal rate

c. Effect of cutting depth (d)

$\mathrm{HO}=$ There is no significant effect of the cutting depth factor (d) on the material removal rate

$\mathrm{H} 1$ = There is a significant influence from the cutting depth factor $(\mathrm{d})$ on the material removal rate

If Fcoun $t>$ FTabel: Reject H0 or Fcount $\leq$ FTabel: A

TABLE V. ANOVA MEAN MATERIAL REMOVAL RATE

\begin{tabular}{|c|c|c|c|c|c|}
\hline Source & DF & SS & MS & F-VALUE & PC \\
\hline $\mathbf{v}$ & 2 & 75032 & 37516 & 2,21 & \\
\hline $\mathbf{f z}$ & 2 & 11818 & 5909 & 0,348 & \\
\hline $\mathbf{d}$ & 2 & 707935 & $4 \mathrm{E}+05$ & 20.851 & $81,33 \%$ \\
\hline Error & 2 & 33951 & 16976 & & $18,67 \%$ \\
\hline Total & 8 & 828737 & & & $100 \%$ \\
\hline
\end{tabular}

The conclusion of these results is that there is a significant effect of the cutting depth factor on the average MRR value.
TABLE VI. TUKEY TEST VS MRR

\begin{tabular}{|c|c|c|c|c|}
\hline Depth of cut & N & Mean & \multicolumn{2}{|c|}{ Grouping } \\
\hline 3 & 3 & 769,048 & A & \\
\hline 2 & 3 & 450,506 & A & B \\
\hline 1 & 3 & 82,647 & & B \\
\hline
\end{tabular}

The difference between the third and the first level shows the use of the second level will result in a significant difference in MRR values.

\section{Calculation of S/N Matrics Ratio, Norm dan Weight} Matrics

TABLE VII. S/N MATRICS RATIO, NORM AND WEIGHT MATRICS

\begin{tabular}{|c|c|c|c|c|c|c|}
\hline \multirow[b]{2}{*}{ No } & \multicolumn{2}{|c|}{ Data S/N Ratio } & \multicolumn{2}{|c|}{ Norm Matrix } & \multicolumn{2}{|c|}{ Weight Matrix } \\
\hline & $\begin{array}{c}E \\
\text { cutting }\end{array}$ & $M R R$ & E cutting & $M R R$ & $\begin{array}{c}E \\
\text { cuting }\end{array}$ & $M R R$ \\
\hline $\mathrm{n} 1$ & $\begin{array}{c}- \\
14,8893 \\
\end{array}$ & 32,7742 & 0,3841 & 0,2182 & 0,5624 & 0,3218 \\
\hline $\mathrm{n} 2$ & $\begin{array}{c}- \\
15,2149 \\
\end{array}$ & 493.909 & 0,3925 & 0,3288 & 0,5747 & 0,4849 \\
\hline n3 & $\begin{array}{c}- \\
14,6302 \\
\end{array}$ & 56,3089 & 0,3775 & 0,3749 & 0,5526 & 0,5528 \\
\hline $\mathrm{n} 4$ & $\begin{array}{c}- \\
14,2179 \\
\end{array}$ & 50,9617 & 0,3393 & 0,3393 & 0,537 & 0,5003 \\
\hline $\mathrm{n} 5$ & $\begin{array}{c}- \\
13,1495 \\
\end{array}$ & 58,1213 & 0,387 & 0,387 & 0,4967 & 0,5706 \\
\hline n6 & $-8,1812$ & 39,7533 & 0,2647 & 0,2647 & 0,309 & 0,393 \\
\hline $\mathrm{n} 7$ & $\begin{array}{c}- \\
14,6672 \\
\end{array}$ & 58,5643 & 0,3899 & 0,3899 & 0,554 & 0,575 \\
\hline $\mathrm{n} 8$ & $-8,3516$ & 40,6039 & 0,2703 & 0,2703 & 0,3155 & 0,3986 \\
\hline n9 & $\begin{array}{c}- \\
10,4012 \\
\end{array}$ & 56,9443 & 0,3791 & 0,3791 & 0,3929 & 0,5591 \\
\hline \multicolumn{5}{|c|}{$\max$} & 0,5747 & 0,575 \\
\hline \multicolumn{5}{|c|}{$\min$} & 0,309 & 0,3218 \\
\hline
\end{tabular}

In this ANOVA test the error value $(\alpha)$ is $5 \%$. Here are the hypotheses used.

a. Effect of cutting speed (v)

$\mathrm{H} 0=$ There is no significant effect of cutting speed factor (v) on energy consumption

$\mathrm{H} 1 \mathrm{=}$ There is a significant effect of cutting speed factor (v) on energy consumption

b. Influence effect (fz)

$\mathrm{H} 0=$ There is no significant effect of feed factor (fz) on energy consumption

$\mathrm{H} 1=$ There is a significant influence of the feed factor (fz) on energy consumption

c. Effect of cutting depth (d)

$\mathrm{HO}=$ There is no significant influence from the cutting depth factor (d) on energy consumption

$\mathrm{H} 1$ = There is a significant influence from the cutting depth factor (d) on energy consumption

If Fcount $>$ FTabel: Reject H0 or Fcount $\leq$ FTabel: Accept H0 
TABLE VIII. ANOVA S/N MATRICS RATIO CONSUMPTION ENERGY

\begin{tabular}{|c|c|c|c|c|c|}
\hline Source & DF & SS & MS & F-VALUE & PC \\
\hline $\mathbf{v}$ & 2 & 24,103 & 12,051 & 89,428 & $36,23 \%$ \\
\hline $\mathbf{f z}$ & 2 & 19,294 & 9,647 & 71,586 & $28,92 \%$ \\
\hline $\mathbf{d}$ & 2 & 22,126 & 11,063 & 82,092 & $33,22 \%$ \\
\hline Error & 2 & 0,27 & 0,1348 & & $1,64 \%$ \\
\hline Total & 8 & 65,792 & & & $100 \%$ \\
\hline
\end{tabular}

Based on this, it can be concluded that there is a significant effect of all treatment factors on the average response value of energy consumption.

TABLE IX. TUKEY TEST FACTOR VS S/N MATRICS RATIO

\begin{tabular}{|c|c|c|c|c|}
\hline \multirow{4}{*}{} & Level & N & Mean & Grouping \\
\hline \multirow{3}{*}{ Cutting Speed } & 1 & 3 & $-14,9$ & $\mathrm{~B}$ \\
\cline { 2 - 5 } & 2 & 3 & $-11,9$ & $\mathrm{~A}$ \\
\cline { 2 - 5 } & 3 & 3 & $-11,1$ & $\mathrm{~A}$ \\
\hline \multirow{3}{*}{ Feed } & 1 & 3 & $-14,6$ & $\mathrm{~B}$ \\
\cline { 2 - 5 } & 2 & 3 & $-12,2$ & $\mathrm{~A}$ \\
\cline { 2 - 5 } & 3 & 3 & $-11,1$ & $\mathrm{~A}$ \\
\hline \multirow{3}{*}{ Depth of cut } & 1 & 3 & $-10,5$ & $\mathrm{~B}$ \\
\cline { 2 - 5 } & 2 & 3 & $-13,3$ & $\mathrm{~A}$ \\
\cline { 2 - 5 } & 3 & 3 & $-14,1$ & $\mathrm{~A}$ \\
\hline
\end{tabular}

\section{ANOVA Material Removal Rate}

In the ANOVA test, the current error value $(\alpha)$ is $5 \%$. The following is the original statement.

A. Key cutting speed (v)

$\mathrm{H} 0=$ There is no significant factor of cutting speed factor $(\mathrm{v})$ on the level of material removal

$\mathrm{H} 1 \mathrm{l}$ there is a significant effect of cutting speed factor $(\mathrm{v})$ on the rate of material removal

b. Influence effect (fz)

$\mathrm{HO}=$ There is no significant factor of feed factor (fz) on material removal rate

$\mathrm{H} 1$ = significant influence of infeed factor (fz) on the level of material removal

c. Cutting depth measurement (d)

$\mathrm{H} 0=$ There is no significant factor from the cutting depth factor (d) to the rate of material removal

$\mathrm{H} 1$ = there is a significant influence from the cutting depth factor (d) on the rate of material removal

If Fcount> FTabel: Reject H0 or Fcount $\leq$ FTabel: Accept H0 TABLE X. ANOVA S/N RATIO MATERIAL RWMOVAL RATE

\begin{tabular}{|c|c|c|c|c|c|}
\hline Source & DF & SS & MS & F-VALUE & PC \\
\hline $\mathbf{v}$ & 2 & 52,382 & 26,191 & 10251,75 & $7,34 \%$ \\
\hline $\mathbf{f z}$ & 2 & 19,152 & 9,576 & $3.748,220$ & $2,68 \%$ \\
\hline $\mathbf{d}$ & 2 & 642,39 & 321,144 & $125.702,700$ & $89,98 \%$ \\
\hline Error & 2 & 0,005 & 0,003 & & $0,003 \%$ \\
\hline Total & 8 & 713,83 & & & $100 \%$ \\
\hline
\end{tabular}

In table $\mathrm{X}$, it can be seen that the cutting depth factor has the greatest effect on changes in MRR variance values .

E. Tukey Test Factor Vs S/N Ratio MRR.

TABLE XI. ANOVA S/N RATIO MATERIAL REMOVAL RATE

\begin{tabular}{|c|c|c|c|c|}
\hline & Level & N & Mean & Grouping \\
\hline \multirow{4}{*}{$\begin{array}{c}\text { Cutting } \\
\text { Speed }\end{array}$} & 1 & 3 & 46,16 & $\mathrm{C}$ \\
\cline { 2 - 5 } & 2 & 3 & 49,61 & $\mathrm{~B}$ \\
\cline { 2 - 5 } & 3 & 3 & 52,04 & $\mathrm{~A}$ \\
\hline \multirow{3}{*}{ Feed } & 1 & 3 & 47,43 & $\mathrm{C}$ \\
\cline { 2 - 5 } & 2 & 3 & 49.372 & $\mathrm{~B}$ \\
\cline { 2 - 5 } & 3 & 3 & 51 & $\mathrm{~A}$ \\
\hline \multirow{3}{*}{$\begin{array}{c}\text { Depth of } \\
\text { cut }\end{array}$} & 2 & 3 & 52,43 & $\mathrm{~A}$ \\
\cline { 2 - 5 } & 3 & 3 & 57,67 & $\mathrm{~A}$ \\
\hline
\end{tabular}

F. Different in positive - negatif Ideal Solution and Overall Performance Indicators

TABLE XII. ANOVA S/N RATIO MATERIAL REMOVAL RATE

\begin{tabular}{|c|c|c|c|c|c|c|}
\hline \multirow{2}{*}{ No } & \multicolumn{2}{|c|}{ Combination } & Si+ & \multirow{2}{*}{ Si- } & \multirow{2}{*}{ OPI } \\
\cline { 2 - 5 } & $\mathbf{v}$ & $\mathbf{f z}$ & $\mathbf{d}$ & & & \\
\hline $\mathbf{1}$ & 1 & 1 & 1 & 0,2535 & 0,2534 & 0,4999 \\
\hline $\mathbf{2}$ & 1 & 2 & 2 & 0,0901 & 0,3118 & 0,7759 \\
\hline $\mathbf{3}$ & 1 & 3 & 3 & 0,0313 & 0,3357 & 0,7759 \\
\hline $\mathbf{4}$ & 2 & 1 & 2 & 0,0836 & 0,2896 & 0,776 \\
\hline $\mathbf{5}$ & 2 & 2 & 3 & 0,0781 & 0,3117 & 0,7996 \\
\hline $\mathbf{6}$ & 2 & 3 & 1 & 0,3236 & 0,0685 & 0,1748 \\
\hline $\mathbf{7}$ & 3 & 1 & 3 & 0,0207 & 0,3523 & 0,9445 \\
\hline $\mathbf{8}$ & 3 & 2 & 1 & 0,3135 & 0,0771 & 0,1975 \\
\hline $\mathbf{9}$ & 3 & 3 & 2 & 0,1825 & 0,2517 & 0,5796 \\
\hline
\end{tabular}

G. Anova Test Combining The Response Of Energy Consumption And MRR

In this ANOVA test the error value $(\alpha)$ is $5 \%$. Here are the hypotheses used.

a. Effect of cutting speed (v)

$\mathrm{H} 0=$ There is no significant effect of cutting speed factor (v) on energy consumption and MRR

$\mathrm{H} 1=$ There is a significant effect of cutting speed factor $(\mathrm{v})$ on energy consumption and MRR

b. Influence effect (fz)

$\mathrm{H} 0=$ There is no significant effect of feed factor (fz) on energy consumption and MRR

$\mathrm{H} 1=$ There is a significant effect of infeed factors (fz) on energy consumption and MRR 
c. Effect of cutting depth (d)

$\mathrm{H} 0=$ There is no significant influence from the cutting depth factor (d) on energy consumption and MRR

$\mathrm{H} 1$ = There is a significant influence from the cutting depth factor (d) on energy consumption and MRR

\section{If Fcount> FTabel: Reject H0 or Fcount $\leq$ FTabel: Accept H0}

TABLE XIII. ANOVA COMBINE RESPONSE OF ENERGY CONSUMPTION AND

\begin{tabular}{|c|c|c|c|c|c|}
\hline Source & DF & SS & MS & F-VALUE & PC \\
\hline $\mathbf{v}$ & 2 & 0,046 & 0,023 & 1061,28 & $6,91 \%$ \\
\hline $\mathbf{f z}$ & 2 & 0,057 & 0,029 & $1.318,330$ & $8,59 \%$ \\
\hline $\mathbf{d}$ & 2 & 0,562 & 0,281 & $12.948,630$ & $84,46 \%$ \\
\hline Error & 2 & 0 & 0 & & $0,03 \%$ \\
\hline Total & 8 & 0,665 & & & $100 \%$ \\
\hline
\end{tabular}

Based on the results of calculations in table XIII, it can be seen that the cutting depth factor has the greatest influence on the combination of energy consumption response and MRR. The magnitude of the effect of the depth of cut is indicated by the percentage contribution (PC) of $84.463 \%$.

\section{H. Tukey Test Significant Factors Combining The Response Of Energy Consumption And MRR}

TABLE XIV. ANOVA COMBINE RESPONSE OF ENERGY CONSUMPTION AND

\begin{tabular}{|c|c|c|c|c|}
\hline \multicolumn{1}{c|}{} & Level & $\mathrm{N}$ & Mean & Grouping \\
\hline \multirow{3}{*}{$\begin{array}{c}\text { Cutting } \\
\text { Speed }\end{array}$} & 1 & 3 & 0,7302 & $\mathrm{~A}$ \\
\cline { 2 - 5 } & 2 & 3 & 0,5834 & $\mathrm{~B}$ \\
\cline { 2 - 5 } & 3 & 3 & 0,5739 & $\mathrm{~B}$ \\
\hline \multirow{2}{*}{ Feed } & 1 & 3 & 0,7401 & $\mathrm{~A}$ \\
\cline { 2 - 5 } & 2 & 3 & 0,5910 & $\mathrm{~B}$ \\
\cline { 2 - 5 } & 3 & 3 & 0,5564 & $\mathrm{~A}$ \\
\hline \multirow{2}{*}{$\begin{array}{c}\text { Depth of } \\
\text { cut }\end{array}$} & 1 & 3 & 0,291 & $\mathrm{C}$ \\
\cline { 2 - 5 } & 2 & 3 & 0,711 & $\mathrm{~B}$ \\
\cline { 2 - 5 } & 3 & 3 & 0,886 & $\mathrm{~A}$ \\
\hline
\end{tabular}

\section{The Best Level Combination}

TABLE XV. THE BEST LEVEL COMBINATION FACTORS

\begin{tabular}{|c|c|c|c|}
\hline Level & $\begin{array}{c}\text { Cutting } \\
\text { Speed } \\
(\mathbf{m m} / \mathbf{m i n})\end{array}$ & $\begin{array}{c}\text { Feeds } \\
(\mathbf{m m} / \text { tooth })\end{array}$ & $\begin{array}{c}\text { Depth of } \\
\text { cut }(\mathbf{m m})\end{array}$ \\
\hline 1 & 0,7302 & 0,7401 & 0,2907 \\
\hline 2 & 0,5834 & 0,591 & 0,7105 \\
\hline 3 & 5739 & 5564 & 0,8863 \\
\hline
\end{tabular}

The best level of all factors with response rates from various levels. Based on the results of the response rate, the highest level is the first speed $(22.8 \mathrm{~mm} /$ minute $)$. The best level for feed factor is the first level $(0.01 \mathrm{~mm} /$ tooth $)$. The best level for depth factor is the third level $(1.5 \mathrm{~mm})$.

\section{CONCLUSION AND FURTHER RESEARCH}

The aim of the research was to develop machining parameters process with the lowest consumption energy. The machining parameters are cutting speed $22.8 \mathrm{~mm} / \mathrm{min}$, feed 0.01 $\mathrm{mm} /$ tooth and depth of cut $1.5 \mathrm{~mm}$. Through this parameters it is expected that the cost of the production process will decrease. In this study the point of view is only the speed of the machining process for energy efficiency, especially the ST 41-3 steel material. Material differences will produce different parameters, so there are still many studies on other material machining processes.

\section{ACKNOWLEDGMENT}

This study was done by supports of the Department of Industrial and Mechanical Engineering, University of Trunojoyo Madura. Authors also thank to all our colleagues who have participated and reviewers of this conference.

\section{REFERENCES}

[1] M. Kaladhar, K. V. Subbaiah, C. S. Rao, \& K. N. Rao, "Application of Taguchi approach and utility concept in solving the multi-objective problem when turning AISI 202 austenitic stainless steel", Journal of engineering science and technology review, vol. 4, no. 1, pp. 55-61, 2011.

[2] M. Kaladhar, K. V. Subbaiah, C. S. Rao, \& K. N. Rao, "Parametric optimization during machining of AISI 304 Austenitic Stainless Steel using CVD coated DURATOMIC ${ }^{\mathrm{TM}}$ cutting insert", International Journal of Industrial Engineering Computations, vol. 3, pp. 577-586, 2012.

[3] V. S. Gadakh, "Parametric optimization of wire electrical discharge machining using TOPSIS method", Advances in Production Engineering \& Management, vol. 7, no. 3, pp. 157-164, 2012.

[4] T. Peng, and X. Xu, "Energy-efficient machining systems: a critical review", International Journal Adven Manufacturing Technology, vol. 72, pp. 1389-1406, 2014.

[5] B. Singaravel and T. Selvaraj, "Optimization Of Machining Parameters In Turning Operation Using Combined Topsis And AHP Method", Tehnicki vjesnik/Technical Gazette, vol. 22, no. 6, pp. 14751480, 2015.

[6] L. An, P. Yang, H. Zhang, M. Chen, "Multi-Objective Optimization for Milling Operations using Genetic Algorithms under Various Constraints", International Journal of Networked and Distributed Computing, Vol. 2, No. 2, pp. 108-114, 2014.

[7] H. B. Wang, H. F. Ting, J. T. Chen, \& D. S.Wang, "Optimizing Multiple Quality Characteristics by Taguchi Method and Topsis Algorithm", International Journal of Organizational Innovation (Online), vol. 4, no. 2, pp. 49-63, 2011.

[8] L. M. Maiyar, R. Ramanujam, K. Venkatesan \& J. Jerald, "Optimization of machining parameters for end milling of Inconel 718 super alloy using Taguchi based grey relational analysis", Procedia Engineering, vol. 64, pp. 1276-1282, 2013.

[9] Y.F. Hsiao., Y.S. Tarng., and K. Y. Kung, "The use of grey-based Taguchi methods to determine Process Parameter of linear motion guide with Multiple Performance Characteristics", Proceedings of the 9th Joint Conference on Information Sciences (JCIS), pp. 1-8, 2006.

[10] Intelitek, ProMill 8000 CNC Machining Center, Manchester: Intelitek Inc., 2014.

[11] Widia-Hanita, Solid End Mills \& Holemaking, Latrobe: Widia Products Group, 2015

[12] Hioki, 3286-20 Clamp on Power Hitester Power Measuring Instruments, . Shanghai : Hioki E E Corporation, 2003 